\title{
Environmentally relevant concentrations of fluconazole alter the embryonic development, oxidative status, and gene expression of NRF1, NRF2, WNT3A, WNT8A, NRD1, and NRD2 of Danio rerio embryos
}

\author{
Francisco Escobar-Huerfano, Gustavo Axel Elizalde-Velázquez, Leobardo Manuel Gómez-Oliván, José \\ Manuel Orozco-Hernández, Karina Elisa Rosales-Pérez, Hariz Islas-Flores, María Dolores Hernández- \\ Navarro
}

Laboratorio de Toxicología Ambiental, Facultad de Química, Universidad Autónoma del Estado de México, Paseo Colón Intersección Paseo Tollocan, Colonia Residencial Colón, Toluca, Estado de México, CP 50120, Mexico.

\begin{abstract}
Correspondence to: Dr. Leobardo Manuel Gómez-Oliván, Laboratorio de Toxicología Ambiental, Facultad de Química, Universidad Autónoma del Estado de México, Paseo Colón Intersección Paseo Tollocan, Colonia Residencial Colón, Toluca, Estado de México, CP 50120, México. E-mail: Imgomezo@uaemex.mx; Igolivan74@gmail.com
\end{abstract}

\begin{abstract}
How to cite this article: Escobar-Huerfano F, Elizalde-Velázquez GA, Gómez-Oliván LM, Orozco-Hernández JM, Rosales-Pérez $\mathrm{KE}$, Islas-Flores $\mathrm{H}$, Hernández-Navarro MD. Environmentally relevant concentrations of fluconazole alter the embryonic development, oxidative status, and gene expression of NRF1, NRF2, WNT3A, WNT8A, NRD1, and NRD2 of Danio rerio embryos. Water Emerg Contam Nanoplastics 2022;1:4. https://dx.doi.org/10.20517/wecn.2021.03
\end{abstract}

Received: 2 Dec 2021 First Decision: 20 Jan 2022 Revised: 9 Feb 2022 Accepted: 14 Feb 2022 Published: 21 Feb 2022

Academic Editor: Antonio Ginebreda Copy Editor: Xi-Jun Chen Production Editor: Xi-Jun Chen

\begin{abstract}
Up to date, there is little information published concerning fluconazole (FCZ) toxicity at environmentally relevant concentrations. Bearing in mind the above background of $F C Z$, we aimed to evaluate the embryotoxic effects environmentally relevant concentrations of FCZ (800-1000 ng/L) may induce in Danio rerio. Moreover, we also wanted to prove whether these FCZ concentrations could generate oxidative stress and alter the expression of several genes related to the antioxidant mechanisms, sterol and retinol biosynthesis, and embryogenesis. Our findings demonstrate that FCZ, at all concentrations, induced pericardial edema, yolk sac deformation, scoliosis, and tail malformation in embryos. Moreover, we also demonstrated this drug altered the redox equilibrium of fish, promoting the production of lipoperoxidation level, hydroperoxide content, and protein carbonyl content in a
\end{abstract}


concentration-dependent manner. Concerning gene expression, FCZ downregulated wingless-type MMTV integration site family member 3a (WNT3A), wingless-type MMTV integration site family member 8a (WNT8A), $\mathrm{N}$-arginine dibasic convertase 1 (NRD1), and $\mathrm{N}$-arginine dibasic convertase 2 (NRD2) and upregulated cytochrome P450 family 26 subfamily a member 1 (CYP26A1), cytochrome P450 family 26 subfamily a member 1B (CYP261B), nuclear respiratory factor 1 (NRF1), and nuclear respiratory factor 2 (NRF2) in D. rerio larvae. Collectively, our results point out that FCZ, at low concentrations, may alter the embryogenesis, oxidative status, and expression of several genes in D. rerio embryos via an impairment in sterol and retinol biosynthesis. Thus, our results provide some of the first evidence that FCZ, even at environmentally relevant concentrations, is harmful to aquatic species.

Keywords: Fluconazole, embryonic disruption, oxidative damage, gene alteration, zebrafish

\section{INTRODUCTION}

Fluconazole (FCZ) is a fungicide of the azole family that people use in oral and dermal medications to treat fungal infection $s^{[1]}$. Nonetheless, we can also find it in household products such as soap, shampoo, dermal creams, shower gels, and toothpaste ${ }^{[2]}$. In addition, FCZ is widely used as fungicide in agriculture and biocide in a variety of products ${ }^{[3]}$. FCZ enters the ecosystems from human and animal excreta after its metabolization, wastewater treatment plants, wastes coming from pharmaceutical industries, medical centers, households, and hospitals ${ }^{[4]}$. Therefore, the use of FCZ in such a broad range significantly increases its presence in the environment, especially in surface and drinking water ${ }^{[5]}$. Environmental pollution with FCZ is strictly related to its properties such as persistence in soil and water connected with the resistance of this compound towards hydrolytic, photolytic, and biological degradation ${ }^{[4]}$. Even though few authors have studied the occurrence of FCZ in the water matrix, this antifungal drug has reached concentrations up to $27,606 \mathrm{ng} / \mathrm{L}$ in wastewater, $109.6 \mathrm{ng} / \mathrm{L}$ in surface water, and $2100 \mathrm{ng} / \mathrm{L}$ in drinking water [Table 1]. Thus, it is important to keep studying the occurrence and distribution of this drug in the water matrix.

As FCZ is present in the aquatic environment and inhibits cytochrome p450 family 3 subfamily a member 4 (CYP3A4) and cytochrome p450 family 2 subfamily c member 9 (CYP2C9 ${ }^{[16]}$, it may cause undesirable effects in non-target organisms. However, only three studies that we are aware of have studied the toxic effects of FCZ in aquatic species, and, in all of them, the authors have used non-environmentally relevant concentrations. Kim et al. ${ }^{[17]}$, for instance, demonstrated that acute toxicity effects of FCZ were only observed on crustaceans (Thamnocephalus platyurus) and fish (Oryzias latipes) at concentrations over $100 \mathrm{mg} / \mathrm{L}$. Similarly, another study found that the no observed effect concentration level and lowest observed effect concentration level required to lower the growth of green algae (Pseudokirchneriella subcapitata) were 15.3 and $19.6 \mathrm{mg} / \mathrm{L}$, respectively ${ }^{[18]}$.

Moreover, the authors pointed out that the growth inhibition induced in green algae was related to the capacity of FCZ to inhibit the sterol biosynthesis of algae. Thus, FCZ may also influence sterol synthesis in organisms other than bacteria. Finally, another author studied the embryotoxic effects of FCZ in rare minnow (Gobiocypris rarus) embryos and found this antifungal drug generated $100 \%$ death in organisms at $15 \mathrm{mg} / \mathrm{L}^{[19]}$. Furthermore, the authors indicated that FCZ induced body malformations, heart rate reduction, oxidative stress, and acetylcholinesterase (AChE) inhibition and alterations in the gene expression of heat shock protein 70 (hsp70), myostatin protein ( $\mathrm{mstn}$ ), metallothionein $(\mathrm{mt})$, apoptosis protease-activating factor-1 (apaf1), vascular endothelial zinc finger 1 (vezf1), and cytochrome P450 family 1 subfamily A (cyp1a) from a concentration of $0.2 \mathrm{mg} / \mathrm{L}$. In comparison to other triazole fungicides, studies have shown FCZ is more toxic ${ }^{[19]}$. However, more studies are needed to understand the risk that this drug poses to the aquatic environment. 
Table 1. Occurrence of fluconazole in different water matrices

\begin{tabular}{llll}
\hline Country & Matrix & ng/L & Ref. \\
\hline Brazil & Surface water & 98.7 & {$[6]$} \\
& Wastewater & $63-1292$ & {$[7]$} \\
Canada & Drinking water & $35-2100$ & {$[8]$} \\
China & Wastewater & $3-27,606$ & {$[9]$} \\
South Africa & Surface water & 109.6 & {$[10]$} \\
& Wastewater & 302.38 & {$[11]$} \\
Spain & Wastewater & $331-9959$ & {$[12]$} \\
Sweden & Wastewater & $20-95$ & {$[13]$} \\
Switzerland & Wastewater & $<$ LOQ - 120 & {$[14]$} \\
\hline
\end{tabular}

LOQ: Limit of quantification.

Therefore, we aimed to study the embryotoxic effects that FCZ may induce in the freshwater fish D. rerio. We exposed zebrafish embryos to nine environmentally relevant concentrations of FCZ and evaluated the mortality, malformations, and hatching rate. Moreover, we also aimed to determine whether these concentrations of FCZ may disrupt the oxidative status and the gene expression of $D$. rerio embryos.

\section{EXPERIMENTAL}

\section{Ethical statement}

All procedures performed in this study were in fulfillment of the ethical standards of The Ethics and Research Committee of the Autonomous University of the State of Mexico (approval ID: RP.UAEM.ERC.132.2020).

\section{Reagents}

We obtained FCZ (CAS number: 86386-73-4; purity > 98\%) and all other compounds from Sigma-Aldrich. To produce the stock solution, we dissolved $1 \mathrm{~g}$ of FCZ in DMSO and completed the volume to $1 \mathrm{~L}$ with bidistilled water. Moreover, to reach the desired concentrations, we performed several dilutions from the stock solution.

\section{Zebrafish housing}

For the maintenance of D. rerio (AB strain), we housed fish, in a ratio of 1 organism/L, in aquaria of $100 \mathrm{~L}$ that we provided with a UV-sterilized and charcoal-filtered water system. To ensure all aquaria fulfilled the water quality parameters throughout the experiment, we measured the levels of dissolved oxygen, nitrate, nitrite, and un-ionized ammonia in water every other day [Table 2]. Fish were fed two times a day with Spirulina flakes and supplemented once a day with Artemia nauplii.

\section{Embryotoxicity test}

The night before spawning, we located 14 adult zebrafish at a ratio of 1 female/2 male in individual reproduction chambers. Spawning and fertilization took place during sunrise, and, approximately $1 \mathrm{~h} \mathrm{after}$ fertilization, we collected and washed the embryos with water and saline solution ${ }^{[20]}$. Following this, we examined the embryos under a stereoscopic microscope, as described by Kimmel et al. ${ }^{[21]}$, and collected those at the blastula stage $(2.5 \mathrm{hpf})$. Blastula stage embryos were placed in Petri-plates with ultrapure water and incubated at a temperature of $26 \pm 1{ }^{\circ} \mathrm{C}$ until they reached the sphere stage ( $4 \mathrm{hpf}$ ). To assess the embryotoxic effects FCZ may induce in fish, we placed 72 embryos, at the sphere stage ( $4 \mathrm{hpf}$ ), into 24 -well plates, ensuring we put 1 embryo/well. Accordingly, we used three 24-well plates for each concentration of FCZ $(0,800,825,850,875,900,925,950,975$, and $1000 \mathrm{ng} / \mathrm{L})$. We chose these concentrations because all of 
Table 2. Water quality parameters measured in aquaria and 24-well plates

\begin{tabular}{ll}
\hline Water parameters & Value measured \\
\hline Dissolved oxygen & $8.9 \pm 0.4 \mathrm{mg} / \mathrm{L}$ \\
$\mathrm{NO}_{2}{ }^{-}$ & $0.023 \pm 0.005 \mathrm{mg} / \mathrm{L}$ \\
$\mathrm{NO}_{3}{ }^{-}$ & $2.1 \pm 0.6 \mathrm{mg} / \mathrm{L}$ \\
$\mathrm{pH}$ & $7.22 \pm 0.16$ \\
Un-ionized ammonia & $0.009 \pm 0.003 \mathrm{mg} / \mathrm{L}$ \\
\hline
\end{tabular}

them are environmentally relevant. Once we finished filling the plates, we incubated them at $26 \pm 1{ }^{\circ} \mathrm{C}$, ensuring all had natural light/dark periods of $12 \mathrm{~h}$. To assess each endpoint, mortality, hatching rate, and malformations, we counted all dead and malformed embryos at 12, 24, 48, 72, and $96 \mathrm{hpf}$ and recorded whether the embryos hatched at 72 or $96 \mathrm{hpf}$. All these endpoints were evaluated following the protocols of Kimmel et al. ${ }^{[21]}$. Moreover, to score the development of fish through the different times of exposure, we used the scale of Hermsen et al. ${ }^{[22]}$. The determination of this score consisted of performing quantitative and qualitative evaluations of each $D$. rerio embryo exposed to FCZ and was compared with the control embryo, receiving points according to its development phase with respect to time. Embryonic development was assessed considering: (1) tail development; (2) formation of somites; (3) eye development; (4) movement; (5) blood circulation; (6) heartbeat; (7) head-body pigmentation; (8) pigmentation of the tail; (9) appearance of the pectoral fin; (10) mouth protuberance; and (11) hatching. Graphs showing the major malformations induced by FCZ exposure were constructed using IBM SPSS Statistics 22 software. After 96 h of exposure, and once we finished counting the dead embryos, we performed a maximum likelihood linear regression analysis and calculated the lethal concentration $50\left(\mathrm{LC}_{50}\right)$ and the effective concentration of malformations $\left(\mathrm{EC}_{50}\right)$ with their $95 \%$ confidence intervals $(P<0.05)$.

\section{Oxidative stress determination}

For this experiment, we placed 10 systems in aquaria of $10 \mathrm{~L}$ of capacity, ensuring each system had a $1 \mathrm{~g}$ of embryos (approximately 1600 embryos) and following the standards of Elizalde-Velázquez et al. ${ }^{[23,24]}$. We exposed all systems to each of the above FCZ concentrations (Section 2.4: Embryotoxicity test) and maintained a constant temperature of $28 \pm 1{ }^{\circ} \mathrm{C}$. At 72 and $96 \mathrm{hpf}$, half of the surviving organisms were selected and homogenized in phosphate buffer (PBS pH 7.4). Next, we split the homogenate from each system into two Eppendorf tubes. Tube 1 contained $300 \mu \mathrm{L}$ of homogenate and $300 \mu \mathrm{L}$ of trichloroacetic acid (20\%) solution and was used to evaluate the levels of protein carbonylation (POX), lipoperoxidation (LPX), and the hydroperoxide content (HPC). Tube 2 contained $700 \mu \mathrm{L}$ of homogenate and was used to assess the antioxidant activity of the enzymes: catalase (CAT), superoxide dismutase (SOD), and glutathione peroxidase (GPX). Table 3 summarizes the methods we used to measure each of the oxidative stress biomarkers.

\section{Integrated biomarker response analysis}

To calculate the integrated biomarker response (IBR) values of all oxidative stress, we first obtained the ratio between the biomarkers of each treatment group (Xi) and the biomarkers of the control group (Xo). Once we calculated the Xi/Xo ratio, we log-transformed their values (Yi) and then standardized them with the following formula $\mathrm{Zi}=(\mathrm{Yi}-\mu) / \mathrm{s}$, where $\mu$ and $\mathrm{s}$ are the mean and the standard deviation of $\mathrm{Yi}$, respectively. Next, we estimated the biomarker deviation index (A) by performing a difference of $\mathrm{Zi}$ and Zo. Finally, we summed each absolute value of $A$ to get IBR values. With the values of $A$, we depicted the integrated responses of each biomarker in a star plot. 
Table 3. Methods used to assess oxidative stress biomarkers on the embryos

\begin{tabular}{lll}
\hline & Biomarker & Method used \\
\hline Tube 1 & LPx & {$[25]$} \\
& HPx & {$[26]$} \\
Tube 2 & POx & {$[27]$} \\
& SOD & {$[28]$} \\
& GPx & {$[29]$} \\
& CAT & {$[30]$} \\
\hline
\end{tabular}

\section{qRT-PCR}

RNA was isolated from the remaining larvae of the embryotoxicity test by using the RNeasy ${ }^{\circ}$ kit of Qiagen. After isolation, RNA concentrations were determined through the 260/280 ratio using a spectrophotometer (THERMO Scientific NanoDrop 2000/2000c). Moreover, samples purities were assessed by using agarose (1\%) gel electrophoresis. We performed the reverse transcription reactions using $1.0 \mu \mathrm{g}$ of the total RNA and the QuantiTect ${ }^{\circ}$ Reverse Transcription Kit (QIAGEN, Hilden, Germany, REF 205313). Reaction conditions were as follows: $42{ }^{\circ} \mathrm{C}$ for $15 \mathrm{~min}$ and $95^{\circ} \mathrm{C}$ for $3 \mathrm{~min}$. cDNA was used as a template for qRTPCR. Genes tested [Table 4] were involved in different biological pathways connected with the toxicity of FCZ. qRT-PCR was performed using a Rotor-Gene Q (Qiagen). We performed each reaction in a $50 \mu \mathrm{L}$ solution containing $0.3 \mu \mathrm{mol}$ primers, $25 \mu \mathrm{L} 2 \times$ SYBER Green QuantiTec ${ }^{\bullet}$ (QIAGEN, Hilden, Germany), and $500 \mathrm{ng}$ of cDNA template. Reaction conditions were as follows: $94^{\circ} \mathrm{C}$ for $15 \mathrm{~s}$, followed by 35 cycles of $94{ }^{\circ} \mathrm{C}$ for $15 \mathrm{~s}, 60^{\circ} \mathrm{C}$ for $30 \mathrm{~s}$, and $72{ }^{\circ} \mathrm{C}$ for $30 \mathrm{~s}$. B-actin was used as the housekeeping gene to normalize all the samples.

\section{Quantification of FCZ in water}

For sampling, we followed the protocols described by Elizalde-Velázquez et al. ${ }^{[23,24]}$. Briefly, for the embryotoxicity test, we collected $140 \mu \mathrm{L}$ of water from each of the wells of the three plates of each concentration. Accordingly, we gathered $10 \mathrm{~mL}$ of water from each concentration. Concerning the oxidative stress study, we took $10 \mathrm{~mL}$ of water from each system. Water samples for both experiments were gathered at $0,12,24,48,72$, and $96 \mathrm{hpf}$.

For analysis of water samples, we used an Agilent 1260 HPLC system coupled to an API 5500 Qtrap MS equipped with a Turbo V Ion spray source. We achieved separation by using a Gemini C1 8 column and a mobile phase of 70 water:30 acetonitrile $(\mathrm{v} / \mathrm{v})$. The flow rate was kept at $1 \mathrm{~mL} / \mathrm{min}$, and the injection volume was $20 \mu \mathrm{L}$. The calibration standards and quality control samples were prepared by spiking ultrapure water with FCZ at a concentration ranging from 0 to $1100 \mathrm{ng} / \mathrm{L}$. The accuracy of the proposed method was confirmed by spiking ultrapure water with FCZ at three different levels: $80 \%, 100 \%$, and $120 \%$.

\section{Statistics}

We assessed our Hermsen's score, hatching rate, and oxidative stress results with a two-way analysis of variance (ANOVA) followed by a Student-Newman-Keuls post hoc test. For this purpose, we considered time as Factor A and concentration as Factor B and used Sigma Plot 12.3 software. In the case of healthy, dead, and malformed embryos, as well as gene expression, we performed a one-way ANOVA.

\section{RESULTS AND DISCUSSION}

\section{Hermsen's score}

Overall, the Hermsen's score of fish exposed to FCZ decreased in a concentration-dependent manner compared to the control group $[\mathrm{F}(9,100)=1241.359 ; P<0.001 ; n=3]$. Nonetheless, at the concentration of 
Table 4. Genes used for $\mathrm{qRT}$-PCR

\begin{tabular}{llll}
\hline Gene & Forward primer & Reverse primer & Ref. \\
\hline Nrf1 & TTT GGT TCC CGA TGA AGA CG & TGA TTA GCG TGA GAC TGA GC & {$[31]$} \\
Nrf2 & ACC CAA TAG ATC TAC AGA GC & GGT GTT TGG ACA TCA TCT CG & {$[32]$} \\
CYP26A1 & AGG CCA TTA TGA GGG CGT TC & AGT ACT GGC GGT GGT TTC AT & {$[33]$} \\
CYP26B1 & GGG GCA GAG AAT GTG CGT AA & TGT TGT TCT CCT TGG CGC TT & {$[34]$} \\
WNT3A & TACGCCTTCTTCAAGCATCC & CTCTTTGCGCTTTTCTGTCC & {$[35]$} \\
WNT8A & CAAGCAAGGAATTGGAGATG & CGCATTTGACTGTGCAGCAC & {$[36]$} \\
NRD1 & CACAAG AGC GTT CAT CAT CCT & TGG GAA ACA CCA GGA ATC AT & {$[37]$} \\
NRD2 & GGT CGG GAG ATT CAT AGC AG & CGT CCT CGC TTG ACT TCT TT & {$[37]$} \\
\hline
\end{tabular}

Nrf1 and NRf2 are genes involved in the response against free radicals; CYP26A1 and CYP26B1 are genes involved with retinoic acid homeostasis; and WNT3A, WNT8A, and NRD1 are genes related to the processes of organogenesis in the early stages of development.

$875 \mathrm{ng} / \mathrm{L}$, we found an equal score to the one observed in fish exposed to $925 \mathrm{ng} / \mathrm{L}$ [Figure 1]. Moreover, we did not find significant differences between concentrations from 825 to $925 \mathrm{ng} / \mathrm{L}$. The control group did not show any significant delay in the development of fish, reaching the highest Hermsen's score.

\section{Dead and malformed embryos rate}

Figure 2 shows the percentage of healthy, death, and malformed embryos exposed to FCZ. As with the Hermsen's score, we saw a significant decrease in the number of healthy embryos compared to the control group [healthy: $\mathrm{F}(9,20)=65.935 ; P<0.001 ; n=3$; dead: $\mathrm{F}(9,20)=35.988 ; P<0.001 ; n=3$, and malformed: $\mathrm{F}$ $(9,20)=27.580 ; P<0.001 ; n=3]$. Thus, we found the highest percentage of healthy embryos in the control group and the lowest at the concentration of $1000 \mathrm{ng} / \mathrm{L}$. Moreover, we also found that the percentage of dead embryos increased with the concentration. Concerning the percentage of malformed embryos, we did not see significant differences at concentrations from 825 to $900 \mathrm{ng} / \mathrm{L}$.

\section{Main malformations induced by FCZ}

As presented in Figure 3, fish from the control group showed a minimal percentage of malformed embryos (4\%), and the malformations they presented were only related to hypopigmentation. Thus, we do not consider them in this section. As shown in Figure 3, fish exposed to FCZ showed a significant increase in the prevalence of malformations compared with the control group. However, the prevalence of malformations in fish did not show a concentration-dependent trend. For instance, fish in some concentrations presented an increase in the prevalence of yolk sac deformation but in others a decreased incidence.

As shown in Figures 3 and 4, pericardial edema was the most prevalent malformation at all concentrations of FCZ, followed by yolk sac deformation. Nonetheless, in the higher concentrations of FCZ, we saw that the prevalence of scoliosis and tail deformation increased compared to the control group.

\section{Hatching rate}

Besides the malformations above, fish exposed to FCZ showed a significant delay in the hatching process at 72 and $96 \mathrm{hpf}$ compared to the control group $[\mathrm{F}(9,40)=56.988 ; P<0.001 ; n=3]$. The delay in the hatching process was in a concentration-dependent manner for both time points. However, this alteration was even more noticeable at $72 \mathrm{hpf}$ compared to $96 \mathrm{hpf}$ [Figure 5]. Between treatment groups, it is noteworthy to say we did not find significant differences among concentrations from 800 to $875 \mathrm{ng} / \mathrm{L}$. At a concentration of $1000 \mathrm{ng} / \mathrm{L}$, less than $25 \%$ of fish hatched at $72 \mathrm{hpf}$, while, at $96 \mathrm{hpf}$, only $76 \%$ of fish hatched at the same concentration. 


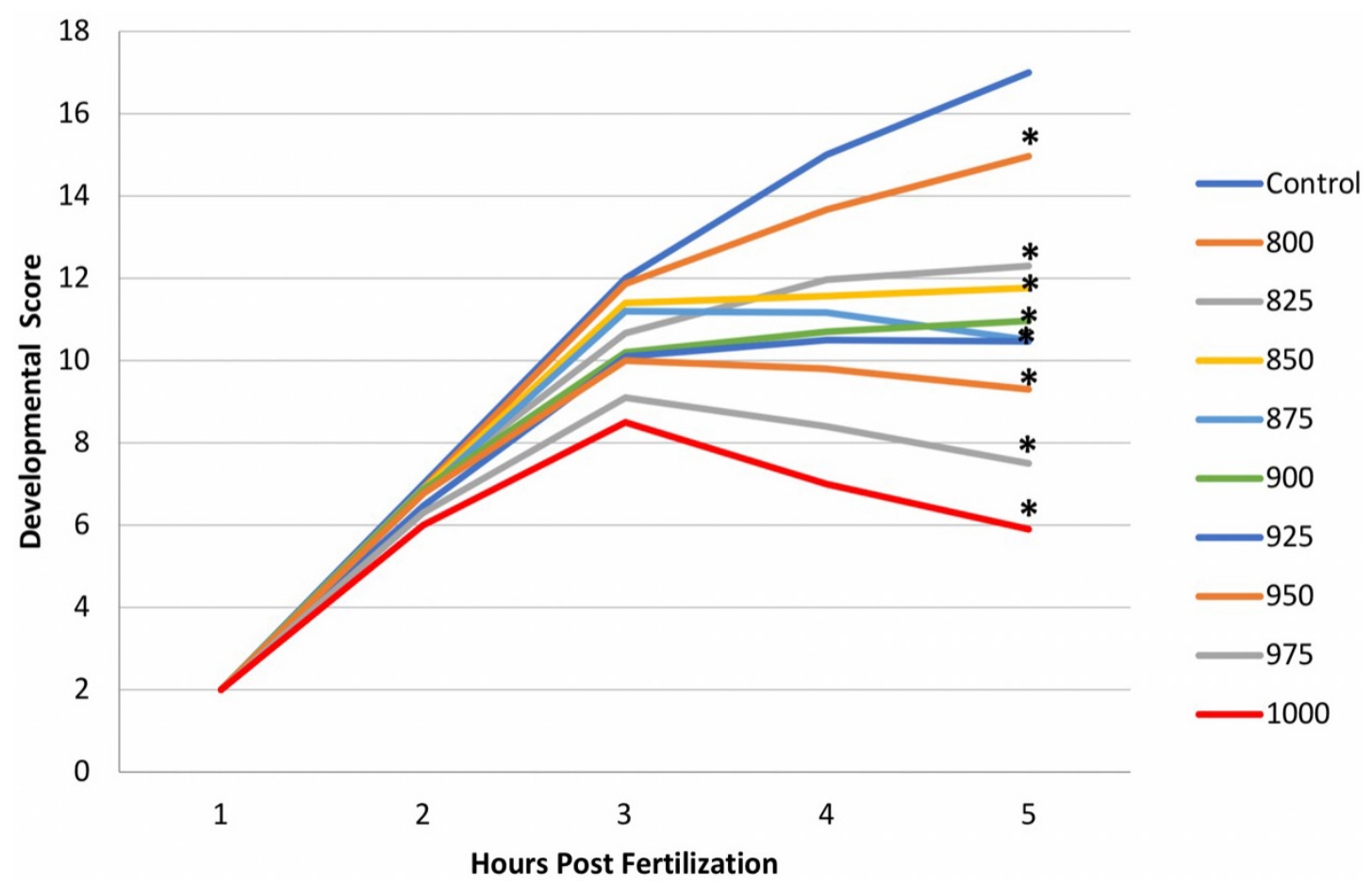

Figure 1. Hermsen's score of embryos exposed to FCZ. Data represent mean \pm standard deviation. *All FCZ concentrations were significantly different from the control group $(P<0.05)$. FCZ: Fluconazole.

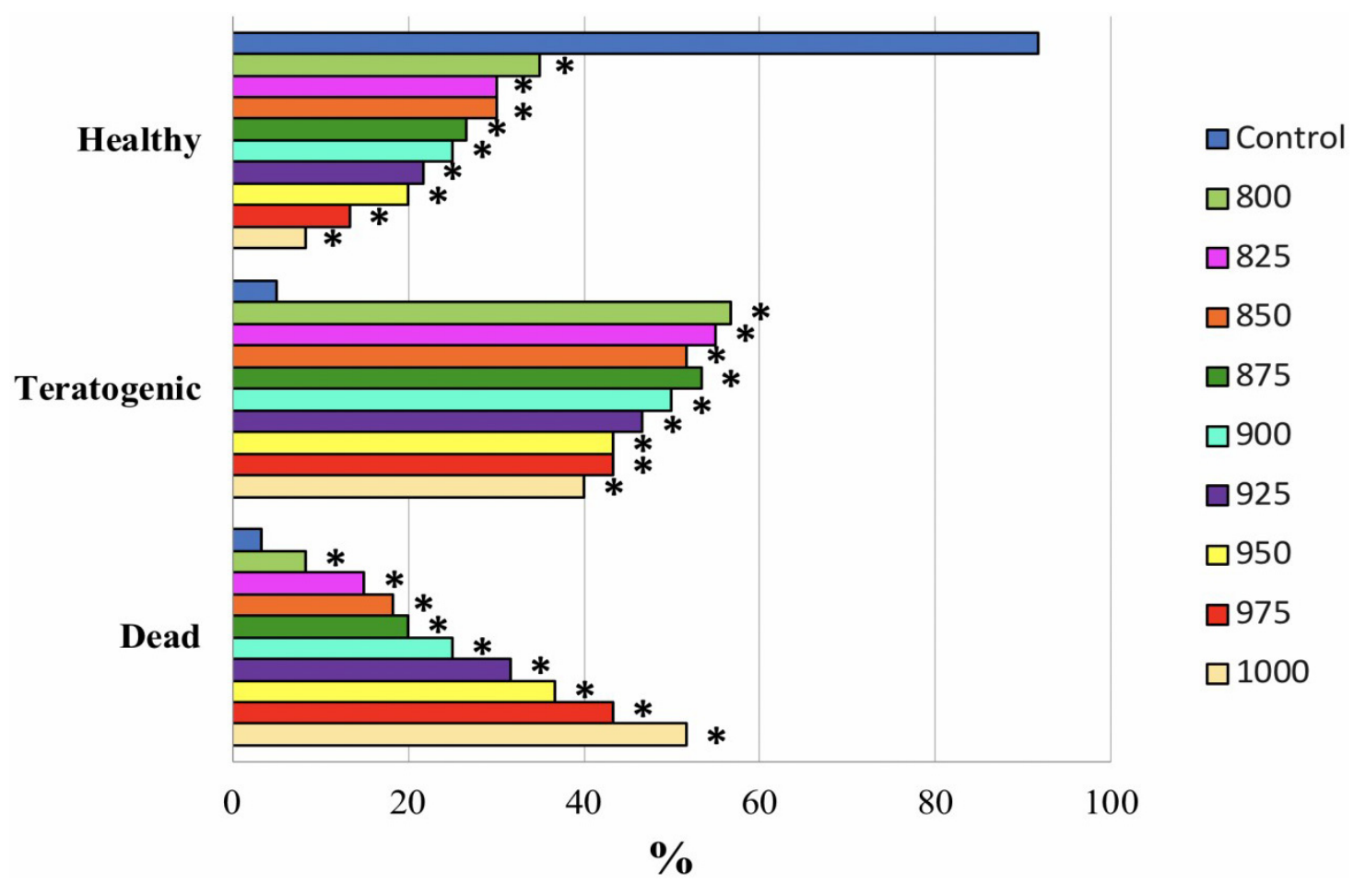

Figure 2. Percentage of dead, teratogenic, and healthy embryos exposed to FCZ. Data represent mean \pm standard deviation. ${ }^{\star} A l l$ FCZ concentrations were significantly different from the control group $(P<0.05)$. FCZ: Fluconazole. 


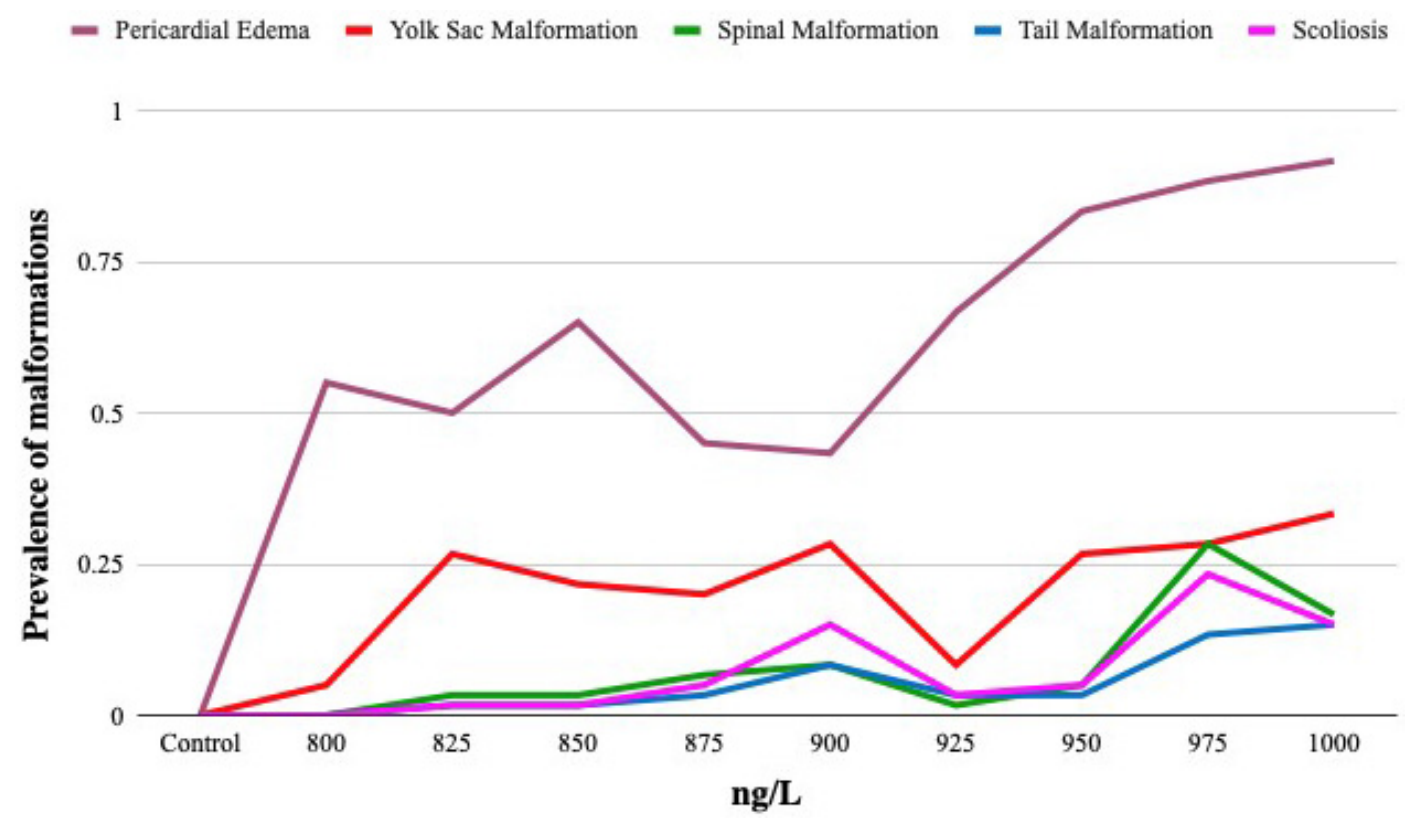

Figure 3. Prevalence of malformations on embryos exposed to FCZ. Data represent mean \pm standard deviation. FCZ: Fluconazole.

\section{Oxidative stress}

According to our results, the enzymatic activity of SOD and CAT in fish exposed to FCZ increased in a concentration-dependent manner compared to the control group [SOD: $\mathrm{F}(9,40)=54.821 ; P<0.001 ; n=3$ and CAT: $F(9,40)=50.763 ; P<0.001 ; n=3]$. Thus, we found significant differences between all the treatment groups and the control group in SOD and CAT, except for the lowest concentration [Figure 6]. Concerning oxidative damage biomarkers, we found that the levels of LPX, HPX, and POX increased with the concentration. Moreover, as with the antioxidant enzymes, we also found significant differences between all the treatment groups and the control group in LPX, HPX, and POX, excluding the lowest concentration [LPX: F $(9,40)=57.560 ; P<0.001 ; n=3$, HPX: F $(9,40)=42.927 ; P<0.001 ; n=3$; POX: F $(9,40)=44.709 ; P<0.001 ; n=3]$. For all oxidative stress biomarkers, we found significant differences between 72 and $96 \mathrm{hpf}$ at all concentrations of FCZ.

\section{IBR}

Since the levels of oxidative damage biomarkers and antioxidant enzymes in fish exposed to FCZ increased, we performed an IBR analysis to determine their tendency. At all concentrations of FCZ, the star plots showed a tendency towards oxidative damage biomarkers [Figure 7]. In addition, even though the IBR values increased from 2.82 to 8.77 , we did not observe any changes in the IBR values among the middle concentrations (825-925 ng/L). Moreover, we also observed a significant decrease in the IBR value of the concentration of $1000 \mathrm{ng} / \mathrm{L}$ compared to the $975 \mathrm{ng} / \mathrm{L}$. Intriguingly, we did not observe significant differences between the IBR values and star plots of 72 and $96 \mathrm{hpf}$.

\section{qRT-PCR}

The gene expression of $N R F_{1}$ and $N R F 2$ increased in a concentration-dependent manner compared to the control group $[\mathrm{F}(9,20)=320.471 ; P<0.001 ; n=3]$. Moreover, we also observed that the expression of $C Y P 26 A 1$ and $C Y P 26 B 1$ increased with the concentration in comparison with the control group $[F(9,20)=$ 291.731; $P<0.001 ; n=3$ ] [Figure 8] Thus, we found significant differences among the treatments as well as between treatments and the control groups for all these genes. Concerning genes WNT3A, WNT8A, NRD1, and $N R D 2$, their expression decreased in a concentration-dependent manner compared to the control 
Control

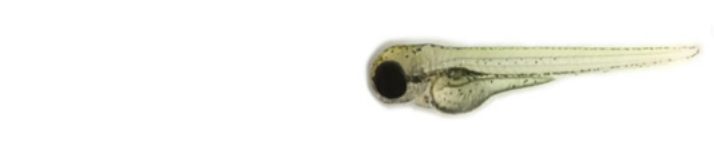

800

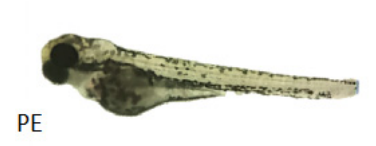

875

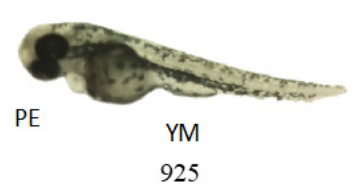

925

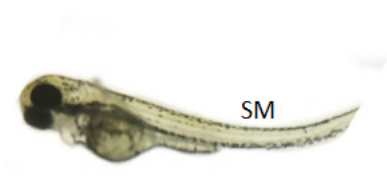

975

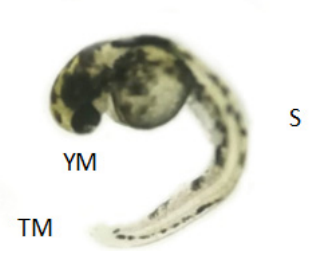

850

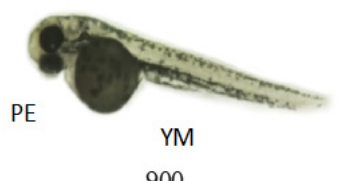

900
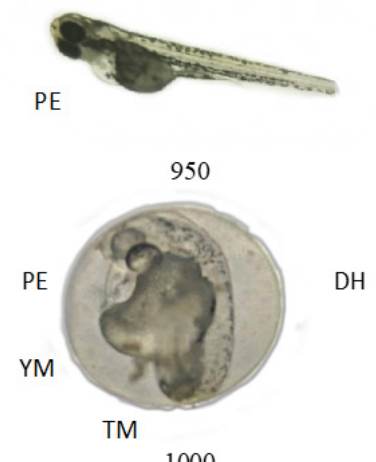

1000

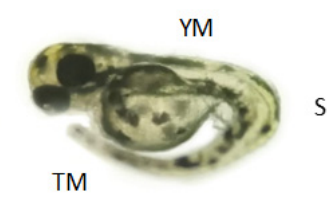

Figure 4. Main malformations found in embryos exposed to FCZ. DH: Delayed hatching; PE: pericardial edema; S: scoliosis; TM: tail malformation; YM: yolk sac malformation; FCZ: fluconazole.

group, with significant differences among all treatment groups $[\mathrm{F}(9,20)=345.195 ; P<0.001 ; n=3 ; \mathrm{F}(9,20)$ $=301.963 ; P<0.001 ; n=3$ ] [Figure 8].

\section{FCZ determination in water samples}

For both experiments, the concentration of FCZ decreased after $96 \mathrm{~h}$ of exposure compared to the nominal concentration. Nonetheless, between the two experiments, the concentrations of FCZ in the oxidative stress experiment decreased more than in the embryotoxicity test [Table 5]. In the oxidative stress experiment and the embryotoxicity test, the concentration of FCZ in the control group was below the limit of quantification. Since the measured concentrations of FCZ did not decrease more than $20 \%$ compared to the nominal concentration, we analyzed all results based on the latter.

Herein, we aimed to determine whether FCZ at environmentally relevant concentrations may alter the development, oxidative status, and the gene expression of NRF1, NRF2, WNT3A, WNT8A, NRD1, and $N R D 2$ of $D$. rerio embryos. Overall, all biomarkers showed either a significant increase or decrease compared to the control group. Below, we discuss each of the results found in this study. 
Table 5. Measured concentrations of FCZ in the water of the embryotoxicity test and the oxidative stress experiment

\begin{tabular}{lll}
\hline Nominal Concentration & $\begin{array}{l}\text { Measured concentration } \\
\text { Embryotoxicity test }\end{array}$ & $\begin{array}{l}\text { Measured concentration } \\
\text { Oxidative stress experiment }\end{array}$ \\
\hline Control & $<\mathrm{LOQ}$ & $<\mathrm{LOQ}$ \\
$800 \mathrm{ng} / \mathrm{L}$ & $718.2 \mathrm{ng} / \mathrm{L}$ & $703.2 \mathrm{ng} / \mathrm{L}$ \\
$825 \mathrm{ng} / \mathrm{L}$ & $734.5 \mathrm{ng} / \mathrm{L}$ & $719.1 \mathrm{ng} / \mathrm{L}$ \\
$850 \mathrm{ng} / \mathrm{L}$ & $750.6 \mathrm{ng} / \mathrm{L}$ & $732.4 \mathrm{ng} / \mathrm{L}$ \\
$875 \mathrm{ng} / \mathrm{L}$ & $773.1 \mathrm{ng} / \mathrm{L}$ & $754.5 \mathrm{ng} / \mathrm{L}$ \\
$900 \mathrm{ng} / \mathrm{L}$ & $801.2 \mathrm{ng} / \mathrm{L}$ & $781.3 \mathrm{ng} / \mathrm{L}$ \\
$925 \mathrm{ng} / \mathrm{L}$ & $818.9 \mathrm{ng} / \mathrm{L}$ & $801.7 \mathrm{ng} / \mathrm{L}$ \\
$950 \mathrm{ng} / \mathrm{L}$ & $849.5 \mathrm{ng} / \mathrm{L}$ & $820.6 \mathrm{ng} / \mathrm{L}$ \\
$975 \mathrm{ng} / \mathrm{L}$ & $863.7 \mathrm{ng} / \mathrm{L}$ & $854.3 \mathrm{ng} / \mathrm{L}$ \\
$1000 \mathrm{ng} / \mathrm{L}$ & $884.4 \mathrm{ng} / \mathrm{L}$ & $870.6 \mathrm{ng} / \mathrm{L}$ \\
\hline
\end{tabular}

Data represent mean \pm standard deviation. LOQ: Limit of quantification (10 ng/L); LOD: limit of detection (5 ng/L).

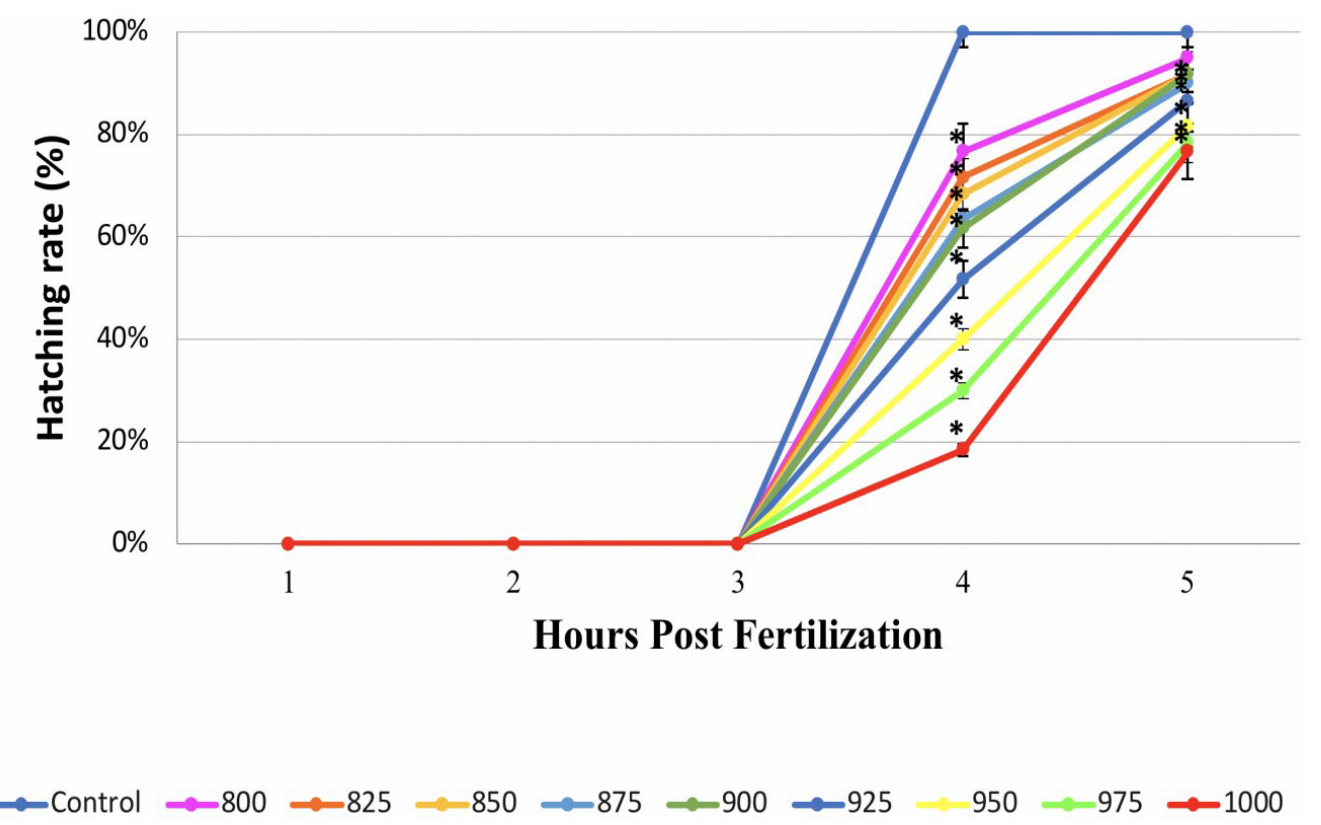

Figure 5. Hatching rate of embryos exposed to FCZ. Data represent mean \pm standard deviation. ${ }^{\star}$ Denotes significant difference compared to control group. FCZ: Fluconazole.

Previously, only one study that we are aware of assessed the embryotoxic effects of FCZ in fish. In this study, the authors pointed out malformations in Gobiocypris rarus embryos become apparent at $1 \mathrm{mg} / \mathrm{L}$ of FCZ; however, they did not mention the type of malformations embryos presented ${ }^{[22]}$. Unlike this study, we demonstrated embryos showed the incidence of pericardial edema, yolk sac deformation, scoliosis, and tail deformation after their exposure to low concentrations of FCZ (800-1000 ng/L). At the concentrations of 825,875 , and $925 \mathrm{ng} / \mathrm{L}$, we found similar prevalences of hypopigmentation and developmental delay. Furthermore, we found no significant differences between the concentrations of 825 and $925 \mathrm{ng} / \mathrm{L}$ because the malformations and developmental delay of the fish were similar. Moreover, we also demonstrated that FCZ significantly delayed the hatching process of $D$. rerio embryos. Alterations in the hatching process are vital to embryos because an anticipated hatch may make organisms more vulnerable to environmental hazards, such as mechanical and osmotic stress and other toxic pollutants present in water ${ }^{[23]}$. Meanwhile, a 

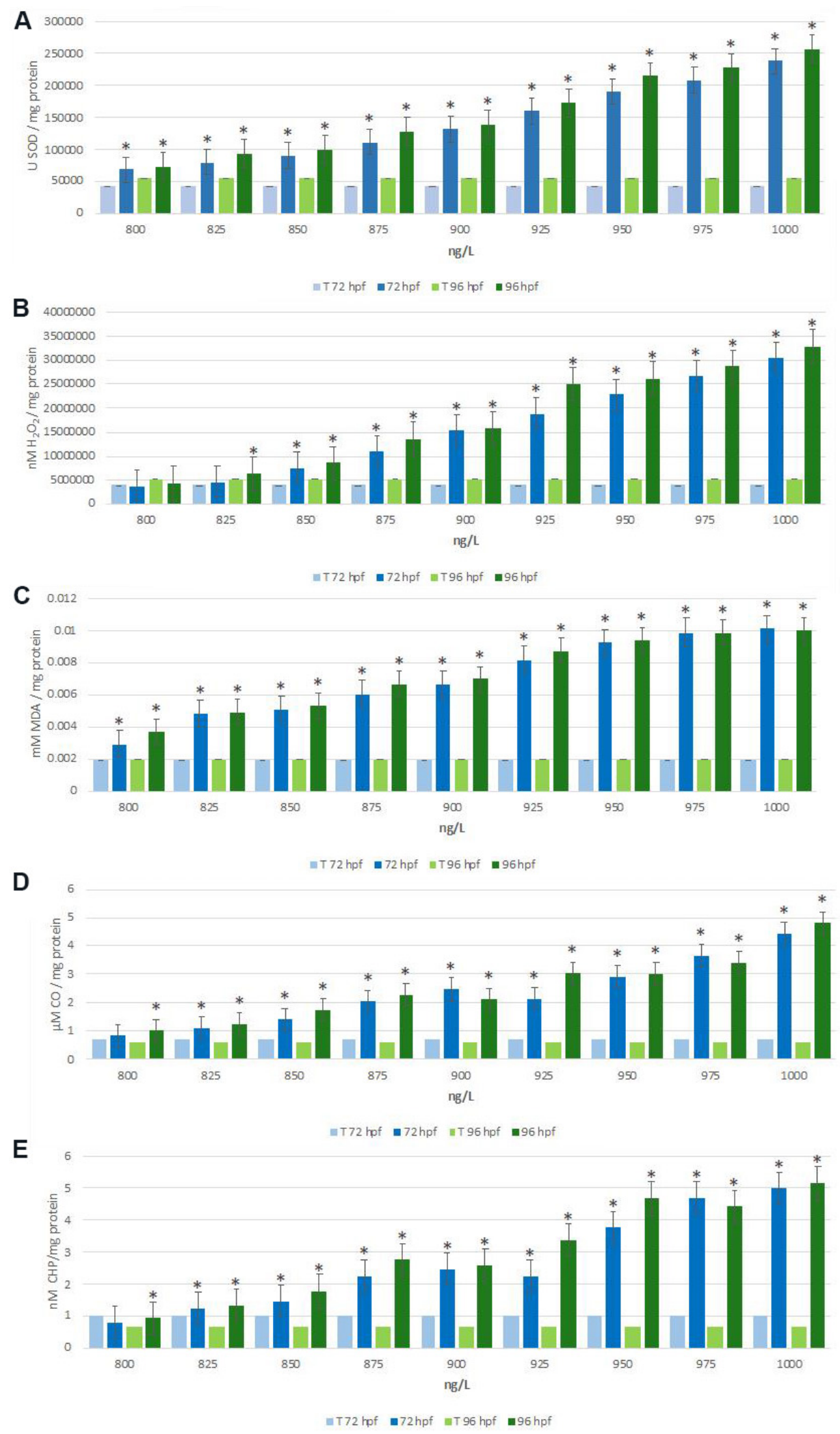

Figure 6. Oxidative stress biomarkers evaluated in fish exposed to FCZ: (A) SOD; (B) CAT; (C) LPX; (D) POX; and (E) HPX. Data represent mean \pm standard deviation. ${ }^{\star}$ Denotes significant difference compared to control group. FCZ: Fluconazole; SOD: superoxide dismutase; CAT: catalase; LPX: lipoperoxidation; POX: protein carbonylation. 


\section{$800 \mathrm{ng} / \mathrm{L}$}

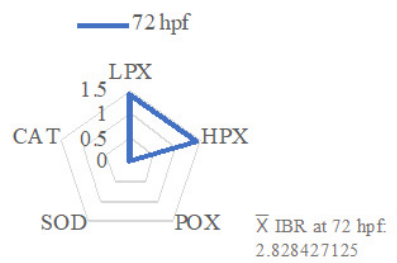

$875 \mathrm{ng} / \mathrm{L}$

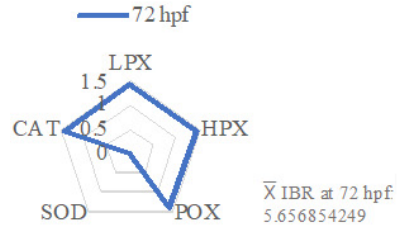

$950 \mathrm{ng} / \mathrm{L}$

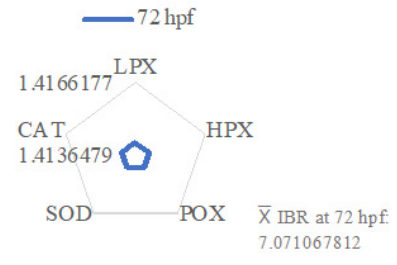

$800 \mathrm{ng} / \mathrm{L}$

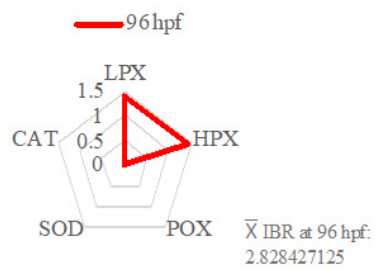

$875 \mathrm{ng} / \mathrm{L}$

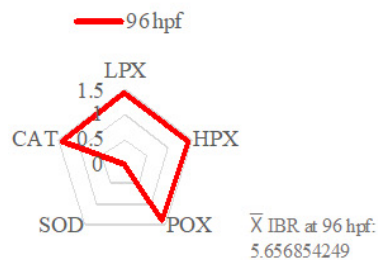

$950 \mathrm{ng} / \mathrm{L}$

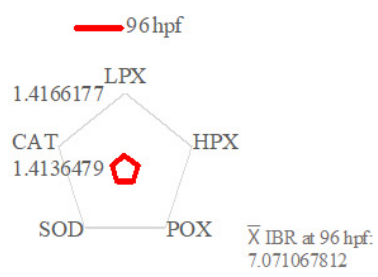

$825 \mathrm{ng} / \mathrm{L}$

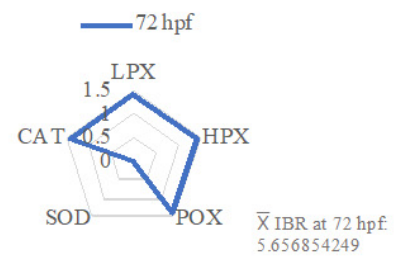

$900 \mathrm{ng} / \mathrm{L}$

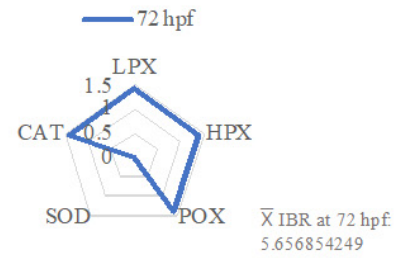

$975 \mathrm{ng} / \mathrm{L}$

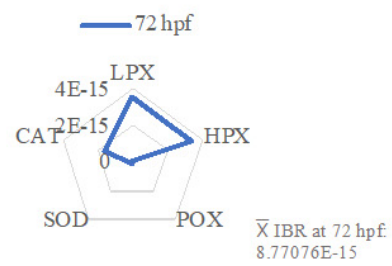

850 ng/L

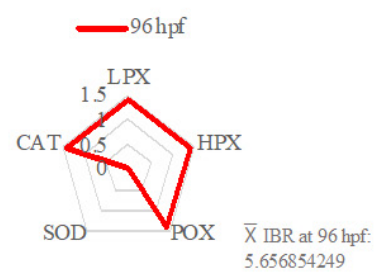

900 ng/L

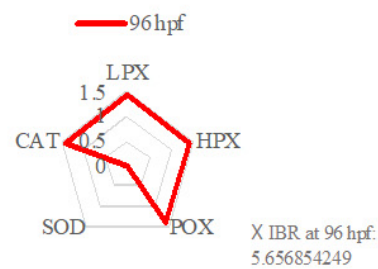

$975 \mathrm{ng} / \mathrm{L}$

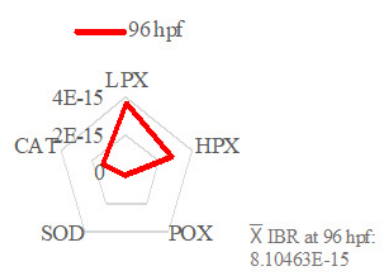

850 ng/L

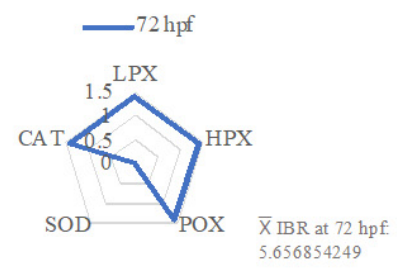

$925 \mathrm{ng} / \mathrm{L}$

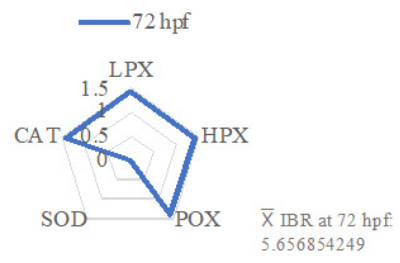

$1000 \mathrm{ng} / \mathrm{L}$

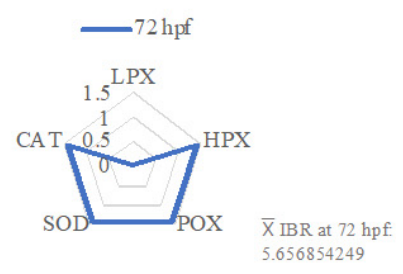

$825 \mathrm{ng} / \mathrm{L}$

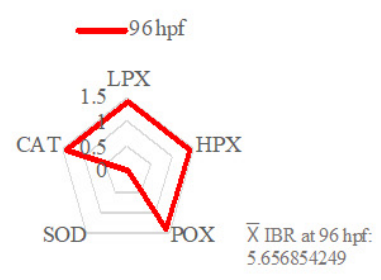

$925 \mathrm{ng} / \mathrm{L}$

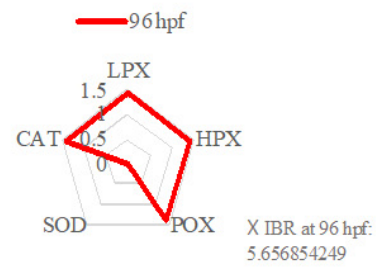

$1000 \mathrm{ng} / \mathrm{L}$

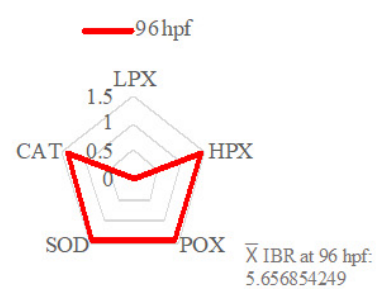

Figure 7. IBR and star charts of oxidative stress biomarkers. IBR: Integrated biomarker response. 

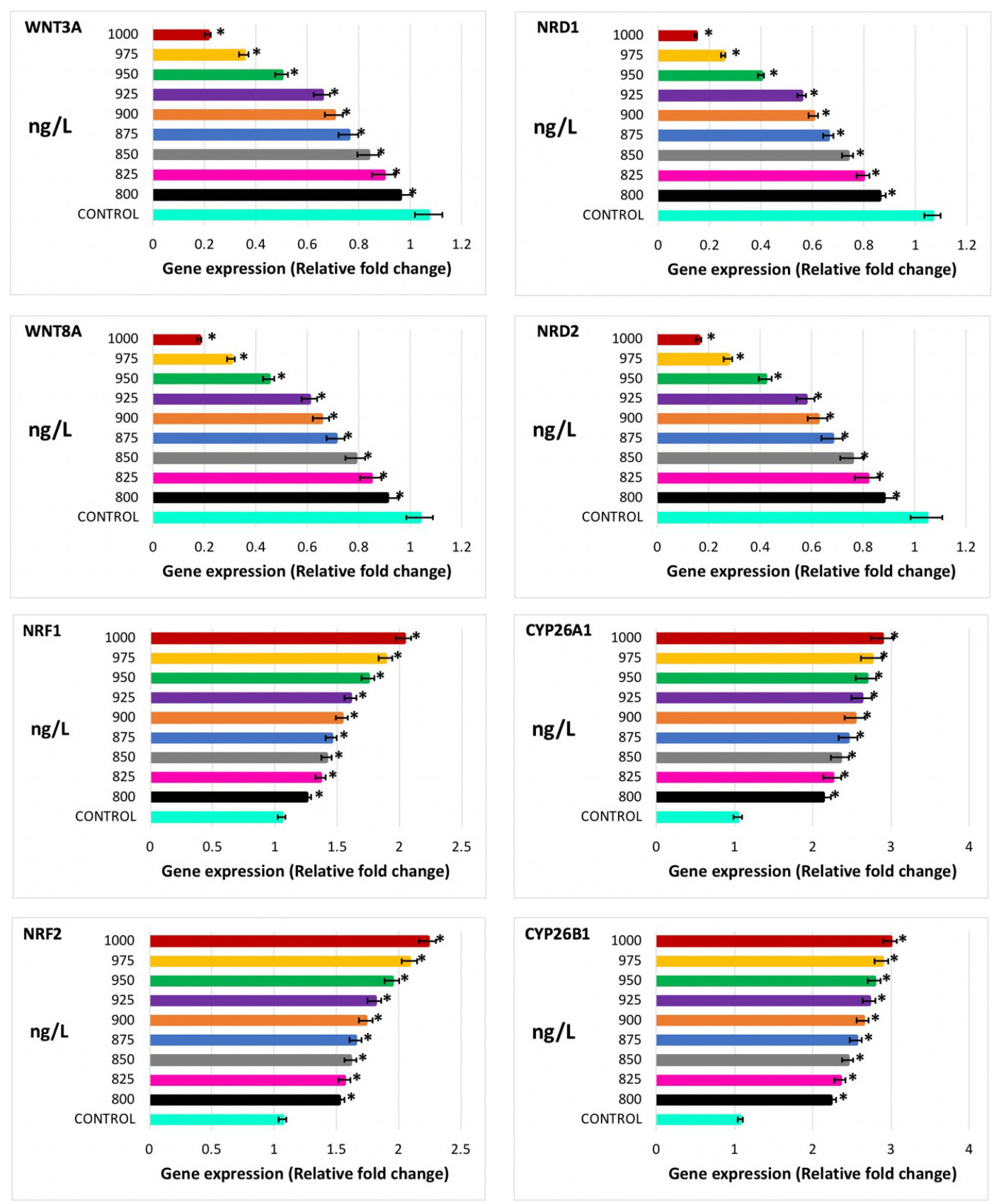

Figure 8. Gene expression of NRF1, NRF2, CYP26A1, CYP26B1, WNT3A, WNT8A, NRD1, and NRD2 in larvae of D. rerio exposed of FCZ. *Denotes significant difference compared to control group.

delay in the hatching process could make embryos more susceptible to other predators. Up to date, authors have indicated that hatching disruptions in fish may be the result of different exogenous and endogenous factors such as oxygen availability, chemical modulators of CNS, hormonal levels, the release of proteolytic enzymes, and toxic agents ${ }^{[35]}$. As the FCZ mechanism of action is related to the inhibition of sterol biosynthesis and sterols are needed for the production of hormones ${ }^{[1,38]}$, we believe FCZ-induced hormonal disruptions are likely to be the mechanism by which this drug delays the hatching process of fish. Nonetheless, future studies are needed to elucidate the mechanism by which FCZ inhibits the hatching process in fish. In agreement with the above-described results, Delattin et al. ${ }^{[39]}$ found that triazoles 
triadimefon, triadimenol, and free triazole $(1,2,4-\mathrm{T})$ inhibit zebrafish hatching by blocking the secretory function of hatching gland cells. Nonetheless, they found this process was rescued by co-incubation with a dopamine D2 receptor antagonist. Thus, this may be another pathway by which FCZ alters the hatching process of fish.

Besides the alterations to embryonic development, FCZ also impaired the redox status of embryos by increasing the levels of SOD, CAT, LPX, POX, and HPX. In agreement with our results, Zhu et al. ${ }^{[19]}$ demonstrated that $0.2 \mathrm{mg} / \mathrm{L}$ of FCZ significantly increased the enzymatic levels of SOD and glutathione s-transferase in Gobiocypris rarus embryos. Moreover, several other studies have indicated that FCZ induced ROS on different fungi ${ }^{[40-43]}$. Although the mechanism by which FCZ induces oxidative stress in organisms is not fully understood, Uthman et al. ${ }^{[41]}$ suggested this process is related to the capacity of FCZ to inhibit the expression of genes encoding metallothioneins (MTs). MTs may control the ROS production via copper binding capacity and by donating electrons ${ }^{[42]}$. However, Peng et al. ${ }^{[40]}$ indicated that FCZ did not affect the gene expression of MT and MT2 in Cryptococcus neoformans. Unlike the above mechanism, we believe FCZ-induced oxidative stress in fish is likely to be due to its inhibiting sterol biosynthesis capacity. Herein, we demonstrated FCZ upregulated the expression of cytochrome P450 family 26 subfamily A member 1 (CYP26A1) and cytochrome P450 family 26 subfamily B member 1 (CYP26B1) in embryos, which might be a response of fish against FCZ sterol biosynthesis inhibition ${ }^{[44]}$. Sterols play a vital role in stabilizing the plasma membrane; however, previous findings demonstrate this is also vital for mitochondrial function and stress tolerance. Thus, inhibition of sterol may impair the function of mitochondria causing ATP depletion and reactive oxygen species (ROS) production. In addition to the downregulation of MT and MT2, we also demonstrated that FCZ upregulated the expression of NRF1 and $\mathrm{NRF} 2$, which may be activated by the increased production of ROS. Gureev et al. ${ }^{[45]}$, for instance, pointed out ROS, particularly $\mathrm{H}_{2} \mathrm{O}_{2}$, are strong Nrf2 activators. The ability to mount an efficient response against the continuous threat posed by exogenous oxidants such as FCZ is essential for cellular homeostasis and survival. Oxidative stress activates transcription of a variety of antioxidant genes through a cis-acting sequence known as antioxidant response element (ARE). Members of the Cap-N-Collar family of transcription factors that bind ARE, including Nrf1 and Nrf2, have been identified. Nrf1 and Nrf2 are expressed in a wide range of tissues and cell types, and both bind ARE as heterodimers with small-Maf proteins. Both Nrf1 and Nrf2 are responsible for regulating the expression of many antioxidant genes including peroxiredoxin-1 (Prx-1), thioredoxin-1 (Txn-1), GCLC (glutamate cysteine ligase catalytic subunit - an enzyme responsible for catalyzing the formation of glutathione), glutathione peroxidase (GPX1), drug metabolizing enzymes (cytochrome P-450s), and several ATP binding cassette (ABC) transporters that are responsible for drug efflux. All of these genes are essential to the maintenance of oxidative homeostasis ${ }^{[46-48]}$.

Once FCZ enters the cell, it inhibits CYP26, promoting the production of retinoic acid (RA), which in excess induces the upregulation of CYP26A1 and CYP26B1 to ensure RA homeostasis ${ }^{[4]}$. RA is essential in embryonic development, as organisms need it for the development of the spinal cord, somites, and eye $\mathrm{e}^{[00,51]}$. Nonetheless, when RA exceeds the normal levels, it may cause many of the same embryonic developmental defects seen with vitamin A deficiency ${ }^{[52]}$. RA does not function alone in controlling the development of embryos; it interacts with other signaling pathways such as WNT, nodal growth differentiation factor (NODAL), fibroblast growth factor, sonic hedgehog, and bone morphogenetic protein. Our results demonstrate that FCZ downregulated, in a concentration-dependent manner, the gene expression of WNT3A, WNT8A, NRD1, and NRD2 in embryos. WNT genes are related to the processes of organogenesis in the early stages of development ${ }^{[53]}$. Meanwhile, NODAL-related genes (NRD) genes encode a secreted ligand of the transforming growth factor-beta (TGF- $\beta$ ) superfamily of proteins that regulates early 
embryonic development ${ }^{[54]}$. This teratogenic pathway is in line with prior findings that demonstrate RA reduced the gene expression of TGF- $\beta$ in rodent embryos ${ }^{[55]}$. Moreover, El Zein et al. ${ }^{[55]}$ pointed out that dysregulation of retinoic acid receptor alpha leads to an impairment of non-canonical WNT signaling, promoting abnormal cell proliferation in mice. Collectively, we believe FCZ-induced embryotoxicity, oxidative stress, and impaired gene expression in fish are the result of the alterations to sterol biosynthesis and RA signaling pathway. Nonetheless, future studies are needed to better understand the mechanism by which FCZ increases the production of ROS and disrupts embryonic development in zebrafish, as well as how these findings affect the fitness and health of fish at environmentally relevant concentrations.

\section{CONCLUSIONS}

FCZ is a triazole fungicide used in multiple medications and personal care products, which, due to its consumption, enters into the aquatic environment. However, the scientific community has barely studied the harmful effects this drug may pose to aquatic species. In this study, we demonstrated that environmentally relevant concentrations of FCZ altered the embryonic development of fish, producing several malformations in them. Moreover, we also demonstrated acute exposure to FCZ impaired the oxidative status of fish, promoting the production of LPX, POX, and HPX in the embryos. Since sterol is implicated in the normal function of mitochondria, we believe FCZ-induced oxidative stress may be the result of altered sterol biosynthesis; however, future studies are needed to elucidate whether this is the mechanism by which FCZ affects fish redox balance. Our results also indicate FCZ altered the expression of WNT, NRD, and CYP26 in the early life stages of D. rerio. Downregulation of these genes could be related to increased production of retinoic acid, as it is implicated in different signaling pathways related to embryogenesis. Increased retinoic acid production is likely to be the mechanism by which FCZ altered the gene expression of the above genes and induced malformations in embryos.

\section{DECLARATIONS}

\section{Acknowledgements}

This study was made possible by the Consejo Nacional de Ciencia y Tecnología (CONACyT). Government of Mexico.

\section{Authors' contributions}

Performed all the exposure experiments: Escobar-Huerfano F, Elizalde-Velázquez GA

Involved in the conception: Gómez-Oliván LM, Escobar-Huerfano F, Elizalde-Velázquez GA

Involved in the design and interpretation of the data: Gómez-Oliván LM, Escobar-Huerfano F, Elizalde-Velázquez GA, Orozco-Hernández JM, Rosales-Pérez KE

The writing of the manuscript with input: Islas-Flores H, Hernández-Navarro MD

\section{Availability of data and materials}

The data will be available in the uaemex repository.

\section{Financial support and sponsorship}

This study was made possible by financial support from the Consejo Nacional de Ciencia y Tecnología México (CONACyT, Project 300727).

\section{Conflicts of interest}

All authors declared that there are no conflicts of interest. 


\section{Ethical approval and consent to participate}

Study protocols and design were approved by the Ethics and Research Committee of the Autonomous University of the State of Mexico (approval ID: RP.UAEM.ERC.132.2020).

\section{Consent for publication}

Not applicable.

\section{Copyright}

(c) The Author(s) 2022

\section{REFERENCES}

1. Chen ZF, Ying GG, Jiang YX, et al. Photodegradation of the azole fungicide fluconazole in aqueous solution under UV-254: kinetics, mechanistic investigations and toxicity evaluation. Water Res 2014;52:83-91. DOI PubMed

2. Chen ZF, Ying GG. Occurrence, fate and ecological risk of five typical azole fungicides as therapeutic and personal care products in the environment: a review. Environ Int 2015;84:142-53. DOI PubMed

3. Frankowski R, Płatkiewicz J, Stanisz E, Grześkowiak T, Zgoła-Grześkowiak A. Biodegradation and photo-Fenton degradation of bisphenol A, bisphenol S and fluconazole in water. Environ Pollut 2021;289:117947. DOI PubMed

4. Alqarni N, Fawzy A, El-gammal B, Toghan A, Hassan NA, Algarni Z. Auspicious water treatment approach. Oxidative degradation of fluconazole and voriconazole antibiotics by $\mathrm{CrO} 3$ in different acidic environments: Kinetics, mechanistic and thermodynamic modelling. Journal of Saudi Chemical Society 2022;26:101396. DOI

5. Patel M, Kumar R, Kishor K, Mlsna T, Pittman CU Jr, Mohan D. Pharmaceuticals of emerging concern in aquatic systems: chemistry, occurrence, effects, and removal methods. Chem Rev 2019;119:3510-673. DOI PubMed

6. de Barros ALC, Schmidt FF, de Aquino SF, Afonso RJCF. Determination of nine pharmaceutical active compounds in surface waters from Paraopeba River Basin in Brazil by LTPE-HPLC-ESI-MS/MS. Environ Sci Pollut Res Int 2018;25:19962-74. DOI PubMed

7. Reis EO, Foureaux AFS, Rodrigues JS, et al. Occurrence, removal and seasonal variation of pharmaceuticals in Brasilian drinking water treatment plants. Environ Pollut 2019;250:773-81. DOI PubMed

8. Santos AV, Couto CF, Lebron YAR, et al. Occurrence and risk assessment of pharmaceutically active compounds in water supply systems in Brazil. Sci Total Environ 2020;746:141011. DOI PubMed

9. Westlund P, Yargeau V. Investigation of the presence and endocrine activities of pesticides found in wastewater effluent using yeastbased bioassays. Sci Total Environ 2017;607-608:744-51. DOI PubMed

10. Huang Q, Wang Z, Wang C, Peng X. Chiral profiling of azole antifungals in municipal wastewater and recipient rivers of the Pearl River Delta, China. Environ Sci Pollut Res Int 2013;20:8890-9. DOI PubMed

11. Assress HA, Nyoni H, Mamba BB, Msagati TAM. Occurrence and risk assessment of azole antifungal drugs in water and wastewater. Ecotoxicol Environ Saf 2020;187:109868. DOI PubMed

12. Assress HA, Selvarajan R, Nyoni H, Ogola HJO, Mamba BB, Msagati TAM. Azole antifungal resistance in fungal isolates from wastewater treatment plant effluents. Environ Sci Pollut Res Int 2021;28:3217-29. DOI PubMed

13. Casado J, Rodríguez I, Ramil M, Cela R. Selective determination of antimycotic drugs in environmental water samples by mixed-mode solid-phase extraction and liquid chromatography quadrupole time-of-flight mass spectrometry. J Chromatogr A 2014;1339:42-9. DOI PubMed

14. Lindberg RH, Fick J, Tysklind M. Screening of antimycotics in Swedish sewage treatment plants--waters and sludge. Water Res 2010;44:649-57. DOI PubMed

15. Kahle M, Buerge IJ, Hauser A, Müller MD, Poiger T. Azole fungicides: occurrence and fate in wastewater and surface waters. Environ Sci Technol 2008;42:7193-200. DOI PubMed

16. Wishart DS, Knox C, Guo AC, et al. DrugBank: a knowledgebase for drugs, drug actions and drug targets. Nucleic Acids Res 2008;36:D901-6. DOI PubMed PMC

17. Kim JW, Ishibashi H, Yamauchi R, et al. Acute toxicity of pharmaceutical and personal care products on freshwater crustacean (Thamnocephalus platyurus) and fish (Oryzias latipes). J Toxicol Sci 2009;34:227-32. DOI PubMed

18. Palomaki AC. Toxicity and mode of action of the pharmaceutical fungicides Fluconazole and Terbinafine to freshwater algae. Available from: https://publications.lib.chalmers.se/records/fulltext/129229.pdf [Last accessed on 18 Feb 2022].

19. Zhu B, Liu L, Gong YX, Ling F, Wang GX. Triazole-induced toxicity in developing rare minnow (Gobiocypris rarus) embryos. Environ Sci Pollut Res Int 2014;21:13625-35. DOI PubMed

20. Westerfield M. The Zebrafish book. A guide for the laboratory use of zebrafish (Danio rerio). 5th ed. Eugene: Univ. Oregon Press; 2007.

21. Kimmel CB, Ballard WW, Kimmel SR, Ullmann B, Schilling TF. Stages of embryonic development of the zebrafish. Dev Dyn 1995;203:253-310. DOI PubMed

22. Hermsen SA, van den Brandhof EJ, van der Ven LT, Piersma AH. Relative embryotoxicity of two classes of chemicals in a modified zebrafish embryotoxicity test and comparison with their in vivo potencies. Toxicol In Vitro 2011;25:745-53. DOI PubMed

23. Elizalde-Velázquez GA, Gómez-Oliván LM, García-Medina S, Islas-Flores H, Hernández-Navarro MD, Galar-Martínez M. 
Antidiabetic drug metformin disrupts the embryogenesis in zebrafish through an oxidative stress mechanism. Chemosphere 2021;285:131213. DOI PubMed

24. Elizalde-Velázquez GA, Gómez-Oliván LM, Islas-Flores H, Hernández-Navarro MD, García-Medina S, Galar-Martínez M. Oxidative stress as a potential mechanism by which guanylurea disrupts the embryogenesis of Danio rerio. Sci Total Environ 2021;799:149432. DOI PubMed

25. Buege JA, Aust SD. [30] Microsomal lipid peroxidation. In: Fleischer S, Packer L, editors. Biomembranes - Part C: biological oxidations. Elsevier; 1978. p. 302-10. DOI

26. Jiang Z, Hunt JV, Wolff SP. Ferrous ion oxidation in the presence of xylenol orange for detection of lipid hydroperoxide in low density lipoprotein. Anal Biochem 1992;202:384-9. DOI PubMed

27. Levine RL, Williams JA, Stadtman EP, Shacter E. [37] Carbonyl assays for determination of oxidatively modified proteins. In: Packer L, editor. Oxygen radicals in biological systems Part C. Elsevier; 1994. pp. 346-57. DOI

28. Misra HP, Fridovich I. The role of superoxide anion in the autoxidation of epinephrine and a simple assay for superoxide dismutase. $J$ Biol Chem 1972;247:3170-5. PubMed

29. Gunzler W, Flohe L. Handbook of methods for oxygen radical research. Boca Raton: CRC Press; 1985.

30. Radi R, Turrens J, Chang L, Bush K, Crapo J, Freeman B. Detection of catalase in rat heart mitochondria. J Biol Chem 1991;266:22028-34. PubMed

31. Sant KE, Hansen JM, Williams LM, et al. The role of Nrf1 and Nrf2 in the regulation of glutathione and redox dynamics in the developing zebrafish embryo. Redox Biol 2007;13:207-18. DOI PubMed PMC

32. Pradhan A, Olsson PE. Inhibition of retinoic acid synthesis disrupts spermatogenesis and fecundity in zebrafish. Gen Comp Endocrinol 2015;217-218:81-91. DOI PubMed

33. Chen JB, Gao HW, Zhang YL, et al. Developmental toxicity of diclofenac and elucidation of gene regulation in zebrafish (Danio rerio). Sci Rep 2014;4:4841. DOI PubMed PMC

34. Zayed Y, Malik R, Qi X, Peng C. Nodal regulates ovarian functions in zebrafish. Mol Cell Endocrinol 2020;511:110821. DOI PubMed

35. De la Paz JF, Beiza N, Paredes-Zúñiga S, Hoare MS, Allende ML. Triazole fungicides inhibit zebrafish hatching by blocking the secretory function of hatching gland cells. Int J Mol Sci 2017;18:710. DOI PubMed PMC

36. Wollam J, Antebi A. Sterol regulation of metabolism, homeostasis, and development. Annu Rev Biochem 2011;80:885-916. DOI PubMed PMC

37. Linares CE, Giacomelli SR, Altenhofen D, Alves SH, Morsch VM, Schetinger MR. Fluconazole and amphotericin-B resistance are associated with increased catalase and superoxide dismutase activity in Candida albicans and Candida dubliniensis. Rev Soc Bras Med Trop 2013;46:752-8. DOI PubMed

38. Mahl CD, Behling CS, Hackenhaar FS, et al. Induction of ROS generation by fluconazole in Candida glabrata: activation of antioxidant enzymes and oxidative DNA damage. Diagn Microbiol Infect Dis 2015;82:203-8. DOI PubMed

39. Delattin N, Cammue BP, Thevissen K. Reactive oxygen species-inducing antifungal agents and their activity against fungal biofilms. Future Med Chem 2014;6:77-90. DOI PubMed

40. Peng CA, Gaertner AAE, Henriquez SA, et al. Fluconazole induces ROS in Cryptococcus neoformans and contributes to DNA damage in vitro. PLoS One 2018;13:e0208471. DOI PubMed PMC

41. Uthman A, Rezaie S, Dockal M, Ban J, Söltz-szöts J, Tschachler E. Fluconazole downregulates metallothionein expression and increases copper cytotoxicity in Microsporum canis. Biochem Biophys Res Commun 2002;299:688-92. DOI PubMed

42. Ruttkay-Nedecky B, Nejdl L, Gumulec J, et al. The role of metallothionein in oxidative stress. Int J Mol Sci 2013;14:6044-66. DOI PubMed PMC

43. Marotta F, Tiboni GM. Molecular aspects of azoles-induced teratogenesis. Expert Opin Drug Metab Toxicol 2010;6:461-82. DOI PubMed

44. del Corral RD, Olivera-martinez I, Goriely A, Gale E, Maden M, Storey K. Opposing FGF and retinoid pathways control ventral neural pattern, neuronal differentiation, and segmentation during body axis extension. Neuron 2003;40:65-79. DOI

45. Gureev AP, Shaforostova EA, Popov VN. Regulation of mitochondrial biogenesis as a way for active longevity: interaction between the Nrf2 and PGC-1 $\alpha$ signaling pathways. Front Genet 2019;10:435. DOI PubMed PMC

46. Schultz MA, Abdel-Mageed AB, Mondal D. The nrf1 and nrf2 balance in oxidative stress regulation and androgen signaling in prostate cancer cells. Cancers (Basel) 2010;2:1354-78. DOI PubMed PMC

47. Ohtsuji M, Katsuoka F, Kobayashi A, Aburatani H, Hayes JD, Yamamoto M. Nrf1 and Nrf2 play distinct roles in activation of antioxidant response element-dependent genes. J Biol Chem 2008;283:33554-62. DOI PubMed PMC

48. Chepelev NL, Zhang H, Liu H, et al. Competition of nuclear factor-erythroid 2 factors related transcription factor isoforms, Nrf1 and Nrf2, in antioxidant enzyme induction. Redox Biol 2013;1:183-9. DOI PubMed PMC

49. Glover JC, Renaud JS, Rijli FM. Retinoic acid and hindbrain patterning. J Neurobiol 2006;66:705-25. DOI PubMed

50. Das BC, Thapa P, Karki R, et al. Retinoic acid signaling pathways in development and diseases. Bioorg Med Chem 2014;22:673-83. DOI PubMed PMC

51. Steinhart Z, Angers S. Wnt signaling in development and tissue homeostasis. Development 2018;145:dev146589. DOI PubMed

52. Bennett JT, Joubin K, Cheng S, et al. Nodal signaling activates differentiation genes during zebrafish gastrulation. Dev Biol 2007;304:525-40. DOI PubMed PMC

53. Colakoglu N, Kukner A, Oner J, Sonmez MF, Oner H, Ozan E. Effects of high dose retinoic acid on TGF-beta2 expression during pancreatic organogenesis. J Mol Histol 2005;36:413-8. DOI PubMed 
54. Chen F, Desai TJ, Qian J, Niederreither K, Lü J, Cardoso WV. Inhibition of Tgf beta signaling by endogenous retinoic acid is essential for primary lung bud induction. Development 2007;134:2969-79. DOI PubMed

55. El Zein RM, Soria AH, Golib Dzib JF, et al. Retinoic acid receptor $\alpha$ as a novel contributor to adrenal cortex structure and function through interactions with Wnt and Vegfa signalling. Sci Rep 2019;9:14677. DOI PubMed PMC 